\title{
Short Communication: Antibacterial potential of Actinomycetes isolated from mangrove sediment in Tanjung Api-Api, South Sumatra, Indonesia
}

\author{
ROZIRWAN", HEBBRI ISKANDAR MUDA, TENGKU ZIA ULQODRY \\ Department of Marine Science, Faculty of Mathematics and Natural Sciences, Universitas Sriwijaya. Jl. Palembang-Prabumulih Km. 32, Indralaya, Ogan \\ Ilir 30128, South Sumatra, Indonesia. Tel./fax.: +62-711-663375, •email: rozirwan@unsri.ac.id \\ Manuscript received: 22 October 2020. Revision accepted: 23 November 2020.
}

\begin{abstract}
Rozirwan, Muda HI, Ulqodry TZ. 2020. Short Communication: Antibacterial potential of Actinomycetes isolated from mangrove sediment in Tanjung Api-Api, South Sumatra, Indonesia. Biodiversitas 21: 5723-5728. Actinomycetes play an important role in the decomposition process of organic matter in mangrove sediments. This study was carried out to identify and evaluate the antagonistic activity of actinomycetes from mangrove sediment against Escherichia coli and Staphylococcus aureus. Identification of actinomycetes was performed based on morphological dan physiological characters. The antagonistic test was carried out against Escherichia coli and Staphylococcus aureus. A total of ten isolates had been successfully isolated and grouped into eight genera, including; Oerskovia H1, Micrococcus H2, Nocardia H3, Sporichtya H5, Corynebacterium H6, Jonesia H7, Actinomyces H10, and Streptomyces H8, H11, H12. Actinomycetes from mangrove sediment were gram-positive bacillus. The shape of the colony varied from circular to filamentous and irregular, with medium and large colony sizes. The colony appears white or yellow. The surface is convex and flat, aerobes and facultative anaerobes; capable of fermenting glucose. Five isolates have very strong growth inhibition activity against E. coli: Nocardia H3 (27.81mm \pm 1.39$)$, Actinomycetes H10 (27.75mm \pm 2.48$)$, Corynebacterium $\mathrm{H} 6(27.69 \mathrm{~mm} \pm 2.39)$, Micrococcus $\mathrm{H} 2(18.55 \mathrm{~mm} \pm 2.44)$, and Streptomyces $\mathrm{H} 8(17.92 \mathrm{~mm} \pm 2.70)$ while Streptomyces $\mathrm{H} 8(24.83 \mathrm{~mm} \pm 2.08)$, and Actinomycetes $\mathrm{H} 10(16.06 \mathrm{~mm} \pm 2.49)$ were active against $S$. aureus.
\end{abstract}

Keywords: Actinomycetes, antagonist test, Escherichia coli, mangrove sediment, Staphylococcus aureus

\section{INTRODUCTION}

Actinomycetes bacteria are grouped into gram-positive bacteria capable of producing various bioactive compounds (Kumar et al. 2019; Mahapatra et al. 2019; Kavitha and Vimala 2020; Shamikh et al. 2020). Actinomycetes are potential as antioxidant, antibacterial, antifungal, antifouling, antiviral (Chandra et al. 2020; Elkhateeb et al. 2020; Gacem et al. 2020; Gong et al. 2020; Hamed et al. 2020; Hassan et al. 2018; Kumar et al. 2020; Matthew et al. 2020; Pereira et al. 2020; Shaala et al. 2020; Yi et al. 2020). Therefore, the potential of marine natural products from actinomycetes collected from mangrove sediments needs to be explored.

Actinomycetes bacteria are found in muddy substrates, especially in mangrove areas. This area contains high nutrients, which come from the mainland through rivers and rainwater runoff. Organic materials from the land will be deposited in the mangrove area to form a thick mud. Mangrove ecosystems contribute very large amounts of nutrients to mangrove sediments (Reef et al. 2010). Mangrove sediments have an abundance of bacteria for the decomposition process that results in increasing soil fertility. It is also reported that actinomycetes can degrade waste (Waithaka et al. 2019).

Actinomycetes are the most widely distributed in mangrove sediments (Suresh et al. 2020). Actinomycetes exhibit antagonistic properties (Tistechok et al. 2019; Dede et al. 2020; Talpur et al. 2020). They can survive in a dynamic mangrove environment, such as changes in salinity, oxygen, temperature, $\mathrm{pH}$, etc. Mangrove areas are greatly influenced by tides, salinity, $\mathrm{pH}$, currents, temperature, and dissolved oxygen (Imamsyah et al. 2020),

The antagonist test was chosen because it is the most effective method for screening the potency of actinomycetes. It is a fast, easy method with tangible results. This test was conducted to determine the inhibitory activity of actinomycetes against pathogenic bacteria, namely Escherichia coli and Staphylococcus aureus. This study aims to isolate, identify, and determine the antibacterial potential of actinomycetes from mangrove sediment.

\section{MATERIALS AND METHODS}

\section{Study area}

Samples of mangrove sediment were taken in December 2018, located in the Tanjung Api-Api mangrove area (Latitude 2²2'17.05' ' S, Longitude 10448'19.74', E) in South Sumatra, Indonesia. It is one of the most important coastal mangroves within the South Sumatra Province. Since 2004, this area has been used as a domestic port with busy shipping activities. 


\section{Sampling and Actinomycetes isolation}

Sediment samples were taken from the mangrove sediment around the root of Avicennia marina using a pipe with a diameter of four inches at a depth of 0 to $25 \mathrm{~cm}$. About $500 \mathrm{~g}$ of the samples were collected and placed in a plastic bag and then stored in a cool box. Actinomycetes from mangrove sediment were isolated based on the method by Dede et al. (2020) and Kavitha and Vimala (2020). Samples were serially diluted. Actinomycetes isolates were cultured on Starch Casein Agar (SCA) medium with a composition of $10 \mathrm{~g}$ of soluble starch, $4 \mathrm{~g}$ of yeast extract, and $16 \mathrm{~g}$ of agar per $1 \mathrm{~L}$ of dH2O. Samples were incubated at $28^{\circ} \mathrm{C}$ for seven days.

\section{Morphological and physiological characterization}

Morphological characters of actinomycetes were observed using a microscope. It includes colony characteristics, hyphal type, and vegetative hyphal growth. Physiological characterization was carried out using several biochemical tests. It includes catalase test, motility test, indole production test, carbohydrate fermentation, TSIA test, Simmons citrate test, Methyl Red test, VogesProskauer test, MIO test, LIA test, urease and gelatin test. Identification of actinomycetes refers to Bergey's Manual Determinative of Bacteriology (Goodfellow et al. 2012)

\section{Antagonists test of actinomycetes isolates against pathogenic bacteria}

The antibacterial potential of actinomycetes was carried out by an antagonistic test against Escherichia coli and Staphylococcus aureus. This method referred to (He et al. 2020; Loqman et al. 2009; Patil et al. 2001; Remya et al. 2008; You et al. 2005). The inhibition zone was measured twice at $24 \mathrm{~h}$ and $48 \mathrm{~h}$, and the average inhibition zone was estimated based on the minimum diameter and added to the maximum diameter.

\section{RESULTS AND DISCUSSION}

\section{Morphological and physiological characteristics of Actinomycetes}

There were ten isolates of Actinomycetes bacteria successfully isolated from mangrove sediments in Tanjung Api-Api water (Figure 1). They are grouped into eight bacterial genera based on their macroscopic, microscopic, and biochemical characteristics. There are three isolates (H8, H11, and H12) identified as the genus Streptomyces.

Morphologically, the ten isolates had different characteristics in shape, size, elevation, color, surface, and margin. The shapes of isolates are generally circular and irregular; only one is filamentous. The sizes of isolates are medium and large, with convex and flat elevations. The colors of the cells are white and yellow, with uneven and evenly margins. All isolates are motile gram-positive, aerobics, and facultative anaerobes. Physiologically, the isolates showed generally positive reactions to sugars (Table 1).

Eight genera of actinomycetes from mangrove sediment samples are as follows: Oerskovia H1, Microccus H2, Nocardia H3, Sporichthya H5, Corynebacterium H6, Jonesia H7, Actinomyces H10, and Streptomyces H8, H11, H12. The genus Streptomyces was identified to be more dominant than others. However, the morphological and physiological characteristics of the three isolates differed slightly. The cell surfaces of $\mathrm{H} 8$ and $\mathrm{H} 11$ were characterized by a smooth, while $\mathrm{H} 12$ was rough. The cell margin of $\mathrm{H} 8$ was even, while $\mathrm{H} 11$ and $\mathrm{H} 12$ were uneven. The cell color of $\mathrm{H} 8$ and $\mathrm{H} 12$ was white, while that of $\mathrm{H} 11$ was yellow. Several differences were also found in the biochemical characteristics of the three isolates. It indicates that the three Streptomyces isolates are thought to be different species.

\section{Antibacterial potential of actinomycetes isolates}

The inhibition zone of actinomycetes isolates collected from mangrove sediments had high variation depending on the bacteria tested and the time of measurement $(24 \mathrm{~h}$ and $48 \mathrm{~h}$ ). The number of isolates that inhibited the growth of Escherichia coli was greater than Staphylococcus aureus (Table 2).

Based on the inhibition zone (Table 2), there are five isolates have very strong and strong inhibitory activity against E. coli, i.e., Genus Nocardia H3 (27.81 mm \pm 1.39), Actinomycetes H10 (27.75 mm \pm 2.48), Corynebacterium H6 (27.69 mm \pm 2.39$)$, Micrococcus $\mathrm{H} 2$ $(18.55 \mathrm{~mm} \pm 2.44)$, and Streptomyces H8 (17.92 $\mathrm{mm} \pm$ 2.70). Two isolates had potent inhibition against $S$. aureus, i.e., Genus Streptomyces H8 (24.83 $\mathrm{mm} \pm 2.08)$ and Actinomycetes $\mathrm{H} 10$ (16.06 mm \pm 2.49$)$.
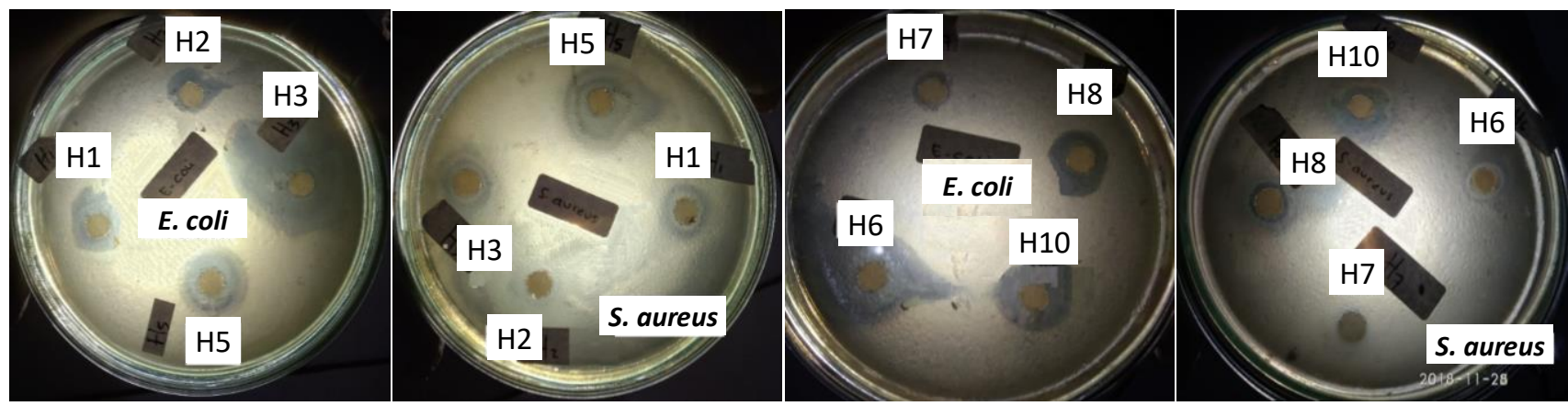

Figure 1. Inhibition zone of actinomycetes isolates against Escherichia coli and Staphylococcus aureus 
Täble 1. Characteristics of Actinomycetes isolated from mangrove sediment

\begin{tabular}{|c|c|c|c|c|c|c|c|c|c|c|}
\hline \multirow{2}{*}{ Characteristics } & \multicolumn{10}{|c|}{ Isolate code } \\
\hline & H1 & H2 & H3 & H5 & H6 & H7 & H8 & H10 & H11 & H12 \\
\hline Shape & Filamentous & Circular & Irregular & Circular & Circular & Irregular & Filamentous & Circular & Filamentous & Filamentous \\
\hline Size & Large & Medium & Large & Medium & Medium & Medium & Medium & Medium & Medium & Medium \\
\hline Elevation & Flat & Convex & Flat & Convex & Convex & Flat & Convex & Convex & Convex & Convex \\
\hline Surface & Smooth & Smooth & Smooth & Smooth & Smooth & Smooth & Smooth & Smooth & Smooth & Rough \\
\hline Margene & Uneven & Evenly & Uneven & Evenly & Evenly & Uneven & Evenly & Uneven & Uneven & Uneven \\
\hline Color & White & Yellow & White & Yellow & Cream yellow & White & White & Cream yellow & Yellow & White \\
\hline Cell shape & Bacillus & Bacillus & Bacillus & Bacillus & Bacillus & Bacillus & Bacillus & Bacillus & Bacillus & Bacillus \\
\hline Motility & - & + & + & + & - & + & - & + & - & - \\
\hline Gram & + & + & + & + & + & + & + & + & + & + \\
\hline Oxygen & $\begin{array}{l}\text { Facultative } \\
\text { anaerobic }\end{array}$ & $\begin{array}{l}\text { Facultative } \\
\text { anaerobic }\end{array}$ & Aerobe & $\begin{array}{l}\text { Facultative } \\
\text { anaerobic }\end{array}$ & Aerobe & $\begin{array}{l}\text { Facultative } \\
\text { anaerobic }\end{array}$ & Aerobe & $\begin{array}{l}\text { Facultative } \\
\text { anaerobic }\end{array}$ & Aerobe & Aerobe \\
\hline Gelatin & - & - & + & - & - & - & + & - & + & + \\
\hline Indole & - & - & - & - & - & - & + & - & + & + \\
\hline Urea & - & - & - & - & + & + & + & + & + & + \\
\hline Citrate & - & - & - & - & - & + & + & - & + & + \\
\hline Lysine iron agar & + & + & - & + & + & + & - & + & - & + \\
\hline Mio & - & - & - & - & - & - & - & - & - & - \\
\hline $\mathrm{NaCl} 4 \%$ & + & + & + & + & + & + & + & + & + & + \\
\hline Methyl red & - & - & - & - & - & - & - & - & - & - \\
\hline Voges Proskauer & + & + & + & - & - & - & - & + & - & + \\
\hline TSIA & Acid & Catalyst & Acid & Acid & Acid & Catalyst & Catalyst & Catalyst & Catalyst & Catalyst \\
\hline Catalase & + & + & + & - & + & + & + & + & + & + \\
\hline Oxidase & + & + & + & - & - & - & + & + & + & + \\
\hline Glucose & + & + & + & + & - & + & + & + & + & + \\
\hline Sucrose & + & + & + & + & - & + & + & + & + & - \\
\hline Lactose & - & - & - & - & - & + & - & - & - & + \\
\hline Esculin & + & - & + & - & - & - & + & + & + & - \\
\hline Arabinose & - & - & + & - & - & + & - & + & + & + \\
\hline Cellobiose & + & - & + & - & - & - & + & + & + & + \\
\hline Galactose & - & + & - & - & - & + & - & - & + & + \\
\hline Fructose & + & + & + & - & - & + & + & + & + & + \\
\hline Maltose & - & + & - & + & - & + & + & + & + & + \\
\hline Melibiose & - & + & - & + & - & + & - & + & + & + \\
\hline Sales & + & - & + & - & - & - & + & + & + & + \\
\hline Inositol & - & - & - & - & - & - & - & - & - & + \\
\hline Mannitol & + & + & + & + & - & + & + & + & + & + \\
\hline Xylose & - & + & - & + & - & + & - & + & - & - \\
\hline Trehalose & - & + & - & + & - & + & + & + & + & + \\
\hline Raffinose & - & - & - & - & - & + & - & + & + & - \\
\hline Rhamnose & - & - & - & - & - & - & - & - & + & + \\
\hline Genus & Oreskovic & Micrococcus & Nocardia & Sporichthya & Corynebacterium & Jonesia & Streptomyces & Actinomyces & Streptomyces & Streptomyces \\
\hline
\end{tabular}


Table 2. The inhibition zone of actinomycetes against Escherichia coli and Staphylococcus aureus

\begin{tabular}{|c|c|c|c|c|c|}
\hline \multirow{3}{*}{ Genus } & \multirow{3}{*}{ Isolates code } & \multicolumn{4}{|c|}{ Inhibition zone (mm) } \\
\hline & & \multicolumn{2}{|c|}{ E. coli } & \multicolumn{2}{|c|}{ S. aureus } \\
\hline & & 24 hour & 48 hour & 24 hour & 48 hour \\
\hline Oerskovia & $\mathrm{H} 1$ & $14.31 \pm 2.21$ & $14.52 \pm 2.33$ & $9.28 \pm 2.09$ & $9.38 \pm 2.12$ \\
\hline Micrococcus & $\mathrm{H} 2$ & $18.45 \pm 2.51$ & $18.55 \pm 2.44$ & $9.35 \pm 2.30$ & $9.58 \pm 2.40$ \\
\hline Nocardia & $\mathrm{H} 3$ & $27.70 \pm 1.34$ & $27.81 \pm 1.39$ & $14.38 \pm 2.80$ & $14.41 \pm 2.81$ \\
\hline Sporichthya & $\mathrm{H} 5$ & $14.13 \pm 2.61$ & $14.30 \pm 2.40$ & $12.08 \pm 2.48$ & $12.18 \pm 2.47$ \\
\hline Corynebacterium & H6 & $27.68 \pm 2.37$ & $27.69 \pm 2.39$ & $9.48 \pm 0.32$ & $9.57 \pm 0.34$ \\
\hline Jones & H7 & $6.71 \pm 0.02$ & $6.81 \pm 0.05$ & $5.80 \pm 0.04$ & $6.39 \pm 0.05$ \\
\hline Streptomyces & H8 & $17.70 \pm 2.72$ & $17.92 \pm 2.70$ & $24.49 \pm 1.71$ & $24.83 \pm 2.08$ \\
\hline Actinomycetes & $\mathrm{H} 10$ & $27.73 \pm 2.51$ & $27.75 \pm 2.48$ & $15.99 \pm 2.53$ & $16.06 \pm 2.49$ \\
\hline Streptomyces & H11 & $5.78 \pm 1.34$ & $5.89 \pm 1.43$ & $4.96 \pm 0.43$ & $4.96 \pm 0.41$ \\
\hline Streptomyces & $\mathrm{H} 12$ & $4.63 \pm 0.99$ & $4.66+0.97$ & - & - \\
\hline
\end{tabular}

\section{Discussion}

Ten isolates were successfully isolated from mangrove sediments in Tanjung Api-Api that are grouped into 8 genera. These genera are widely reported in sediments (AlDhabi et al. 2020; Arifiyanto et al. 2020; Bolorunduro et al. 2019; Elhagrassy 2018; Shah et al. 2017; Abidin et al. 2016). The genus Actinomyces is also reported to be grampositive bacteria and facultatively anaerobic. It can also ferment sugars, catalase, and Voges-Proskauer positive (Goodfellow et al. 2012).

The genus Corynebacterium was also found from sea sediments in Thailand (Leetanasaksakul and Thamchaipenet 2018), the sediment from Valparaíso bay, Chile (Claverías et al. 2019). Corynebacterium is grampositive bacilli and produces catalase (Goodfellow et al. 2012). The genus Jonesia is motile, gram-positive bacilli, catalase-positive with oxidase-negative, does not hydrolyze indole, hydrolyzes urea, and citrate, liquefies, and ferments sugars such as glucose, lactose, and saccharose (Goodfellow et al. 2012). The genus Micrococcus was found in the Nellore coastal regions of Bapatla and Vishakhapatnam, South India (Kumari et al. 2020). Generally, bacterial isolates in the environment are halophilic and have the potential to be applied in industry.

Nocardia is found in tropical mangrove sediments in Malaysia (Lee et al. 2014). This species was found by (Fahmy 2020). (Goodfellow et al. 2012) It has white, orange, pink, and red colony colors, irregular colony forms, gram-positive, aerobic, rod-shaped, motile and non-motile, catalase-positive, and can hydrolyze several types of sugars. It is halophilic and can remodel cellobiose, dextrins, cellulose, and agar with palmitate and stearate, substrates, that are commonly used to degrade cellobiose. (Person et al. 1991). Oerskovia was found by (Dimri et al. 2020). Sporichthya was also found in sediments, a facultatively anaerobic gram-positive bacterium. It is a chemoorganotropic and mesophilic, motile, and sensitive to high temperatures (Ahmad et al. 2019).

The inhibitory zones produced by actinomycetes isolates against pathogenic bacteria were varied. Five isolates showed a strong inhibitory zone, namely, Nocardia (H3), Actinomycetes (H10), Corynebacterium (H6), Micrococcus (H2), and Streptomyces (H8) against E.coli.
The inhibitory zone is presumably related to the production of active antibacterial compounds by these isolates (Ahmad et al. 2019; Al-Farraj et al. 2020; Fahmy 2020; Sapkota et al. 2020). Several previous studies showed that actinomycetes have good antibacterial activity. For example, Nocardia from Indian mangrove ecosystems (Manikkam et al. 2019), Actinomyces from Nipah mangrove sediment (Yanti et al. 2020), Corynebacterium the sediment of Valparaíso bay, Chile (Claverías et al. 2019), Micrococcus from seawater (Kumari et al. 2020), and Streptomyces from mangrove soil sediment (Al-Dhabi et al. 2019; Al-Farraj et al. 2020; Fahmy 2020; Kripra et al. 2020; Sabido et al. 2020).

Five isolates showed more potent antibacterial activity against $E$. coli than $S$. aureus. They were more effective in inhibiting gram-negative bacteria than gram-positive bacteria. Gram-positive bacteria have a thicker cell membrane than gram-negative bacteria (Christofferson et al. 2020). Therefore, the active antibacterial compounds might be easier to penetrate the membrane cell of gramnegative bacteria. Antibacterial activity is also influenced by the method, type, and level of resistance of the tested microbes.

In conclusion, total of ten actinomycetes bacteria isolated from the mangrove sediments in Tanjung Api-Api, South Sumatra, and was grouped into eight genera, i.e., Oerskovia H1, Micrococcus H2, Nocardia H3, Sporichtya H5, Corynebacterium H6, Jonesia H7, Actinomyces H10, and Streptomyces H8, H11, H12. Five isolates showed very strong antibacterial activity; namely, Micrococcus H2, Nocardia H3, Corynebacterium H6, Streptomyces H8, and Actinomycetes $\mathrm{H} 10$ against gram-negative bacteria. Their antibacterial potential is more likely to inhibit gramnegative than gram-positive bacteria. Actinomycetes isolated from mangrove sediment have the potential as natural medicine.

\section{ACKNOWLEDGEMENTS}

We would like to thank the head of the Marine Bioecology Laboratory, Faculty of Mathematics and 
Natural Sciences, Sriwijaya University, Indonesia for supporting facilities in this research.

\section{REFERENCES}

Abidin ZAZ, Malek NA, Zainuddin Z, et al. 2016. Selective isolation and antagonistic activity of actinomycetes from mangrove forest of Pahang, Malaysia. Front Life Sci 9 (1): 24-31. DOI: 10.1080/21553769.2015.1051244.

Ahmad I, Althubiani AS, Dar MS, Qais FA, Abulreesh HH, Bamaga MA, Al-Ghamdi SB, Alshehrei F. 2019. Actinomycetes as continued source of new antibacterial leads. In: Antibacterial Drug Discovery to Combat MDR. Springer Nature Singapore, Singapore.

Al-Dhabi NA, Esmail GA, Ghilan AKM, et al. 2020. Chemical constituents of Streptomyces sp. strain Al-Dhabi-97 isolated from the marine region of Saudi Arabia with antibacterial and anticancer properties. J Infect Pub Heal 13 (2): 235-243. DOI: 10.1016/j.jiph.2019.09.004.

Al-Dhabi NA, Ghilan A-KM, Esmail GA, et al. 2019. Bioactivity assessment of the Saudi Arabian Marine Streptomyces sp. Al-Dhabi90 , metabolic profiling and its in vitro inhibitory property against multidrug-resistant and extended-spectrum beta-lactamase clinical bacterial pathogens. J Infect Pub Heal 12 (4): 549-556. DOI: 10.1016/j.jiph.2019.01.065

Al-Farraj DA, Varghese R, Vágvölgyi C, et al. 2020. Antibiotics production in optimized culture condition using low cost substrates from Streptomyces sp. AS4 isolated from mangrove soil sediment. J King Saud Univ Sci 32 (2): 1528-1535. DOI: 10.1016/j.jksus.2019.12.008.

Arifiyanto A, Surtiningsih T, Ni'matuzahroh, et al. 2020. Antimicrobial activity of biosurfactants produced by actinomycetes isolated from rhizosphere of Sidoarjo mud region. Biocatalyst Agri Biotech 24: 101513. DOI: 10.1016/j.bcab.2020.101513.

Bolorunduro OFD, Adeleye IA, Akinleye MO, et al. 2019. Anticancer potential of metabolic compounds from marine actinomycetes isolated from Lagos Lagoon sediment. J Pharm Anal 9 (3): 201-208. DOI: $10.1016 /$ j.jpha.2019.03.004

Chandra P, Sharma RK, Arora DS. 2020. Antioxidant compounds from microbial sources: A review. Food Res Intl 129: 108849. DOI: 10.1016/j.foodres.2019.108849

Christofferson AJ, Elbourne A, Cheeseman S, et al. 2020 Conformationally tuned antibacterial oligomers target the peptidoglycan of Gram-positive bacteria. J Coll Intl Sci 580: 850-862. DOI: $10.1016 /$ j.jcis.2020.07.090.

Claverías F, Gonzales-Siles L, Salvà-Serra F et al. 2019. Corynebacterium alimapuense sp. nov., an obligate marine actinomycete isolated from sediment of Valparaíso bay, Chile. Intl J Syst Evol Microbiol 69 (3): 783-790. DOI: 10.1099/ijsem.0.003237.

Dede A, Güven K, Şahin N. 2020. Isolation, plant growth-promoting traits, antagonistic effects on clinical and plant pathogenic organisms and identification of actinomycetes from olive rhizosphere. Micro Path 143: 104134. DOI: 10.1016/j.micpath.2020.104134.

Dimri AG, Chauhan A, Aggarwal M. 2020. Antibiotic potential of actinomycetes from different environments against human pathogens and microorganisms of industrial importance: a review. Sci Arc 1 (1): 32-48.

Elhagrassy AF. 2018. Isolation and characterization of actinomycetes from Mural paintings of Snu-Sert-Ankh tomb, their antimicrobial activity, and their biodeterioration. Microbiol Res 216: 47-55. DOI: 10.1016/j.micres.2018.08.005.

Elkhateeb WA, Mohamed MA, Fayad W, et al. 2020. Molecular identification, metabolites profiling, anti-breast cancer, Anticolorectal cancer, and antioxidant potentials of Streptomyces zaomyceticus AA1 isolated from a remote bat cave in Egypt. Res J Pharm Tech 13 (7): 3072-3080. DOI: 10.5958/0974360X.2020.00545.4.

Fahmy NM. 2020. Isolation and characterization of Streptomyces sp. NMF76 with potential antimicrobial activity from mangrove sediment, Red Sea, Egypt. Egypt J Aqua Biol Fish 24 (6): 479-495. DOI: 10.21608/EJABF.2020.117578.

Gacem MA, Khelil AOEH, Boudjemaa B, et al. 2020. Antimicrobial and antioxidant effects of a forest actinobacterium v 002 as new producer of Spectinabilin, Undecylprodigiosin and Metacycloprodigiosin. Curr Microbiol 77 (10): 2575-2583.

Gong Y, Chen LJ, Pan SY, et al. 2020. Antifungal potential evaluation and alleviation of salt stress in tomato seedlings by a halotolerant plant growth-promoting actinomycete Streptomyces sp. KLBMP5084. Rhizosphere 16: 100262. DOI: 10.1016/j.rhisph.2020.100262.

Goodfellow M, Kämpfer P, Busse HJ, et al. 2012. Bergey's manual of systematic bacteriology: volume five the actinobacteria, Part A. Springer, New York.

Hamed AA, Kabary H, Khedr M, et al. 2020. Antibiofilm, antimicrobial and cytotoxic activity of extracellular green-synthesized silver nanoparticles by two marine-derived actinomycetes. RSC Adv 10 (17): 10361-10367. DOI: 10.1039/C9RA11021F.

Hassan SED, Salem SS, Fouda A, et al. 2018. New approach for antimicrobial activity and bio-control of various pathogens by biosynthesized copper nanoparticles using endophytic actinomycetes. J Radiat Res Appl Sci 11 (3): 262-270. DOI: 10.1016/j.jrras.2018.05.003

He H, Hao X, Zhou W, et al. 2020. Identification of antimicrobial metabolites produced by a potential biocontrol Actinomycete strain A217. J Appl Microbiol 128 (4): 1143-1152. DOI: 10.1111/jam.14548.

Imamsyah A, Arthana IW, Astarini IA. 2020. The influence of physicochemical environment on the distribution and abundance of mangrove gastropods in Ngurah Rai Forest Park Bali, Indonesia. Biodiversitas 21: 3178-3188 DOI: 10.13057/biodiv/d210740.

Kavitha S, Vimala RJ. 2020. Screening of marine Actinomycetes for inhibitory activity against biofilm-forming bacteria. J Env Biol 41 (5): 995-1002. DOI: 10.22438/jeb/41/5/MRN-1215.

Kripa N, Reyhanath P, Beevi MR et al. 2020. Isolation of Streptomyces spp. with bioprospecting potential from Mangrove Regions of Ponnani, Kerala, India. J Aqua Biol Fish 8: 1-6.

Kumar P, Kundu A, Kumar M, et al. 2019. Exploitation of potential bioactive compounds from two soil derived actinomycetes, Streptomyces sp. strain 196 and RI. 24. Microbiol Res 229: 126312. DOI: $10.1016 /$ j.micres.2019.126312.

Kumar P, Ling C, Zhou Z, et al. 2020. Chemical diversity of metabolites and antibacterial potential of actinomycetes associated with marine invertebrates from intertidal regions of Daya Bay and Nansha Islands. Microbiology 89 (4): 483-492.

Kumari KS, Shivakrishna P, Al-Attar AM, et al. 2020. Antibacterial and cytotoxicity activities of bioactive compounds from Micrococcus species OUS9 isolated from seawater. J King Saud Univ Sci 32 (6): 2818-2825. DOI: 10.1016/j.jksus.2020.07.003.

Lee LH, Zainal N, Azman AS et al. 2014. Diversity and antimicrobial activities of actinobacteria isolated from tropical mangrove sediments in Malaysia. Sci World J 2014: 1-14. DOI: 10.1155/2014/698178.

Leetanasaksakul K, Thamchaipenet A. 2018. Potential anti-biofilm producing marine actinomycetes isolated from sea sediments in Thailand. Agri Nat Res, 52 (3): 228-233. DOI: 10.1016/j.anres.2018.09.003.

Loqman S, Barka EA, Clément C et al. 2009. Antagonistic actinomycetes from Moroccan soil to control the grapevine gray mold. World $\mathbf{J}$ Microbiol Biotech 25 (1): 81-91.

Mahapatra GP, Raman S, Nayak S et al. 2019. Metagenomics approaches in discovery and development of new bioactive compounds from marine actinomycetes. Curr Microbiol 77: 645-656.

Manikkam R, Pati P, Thangavel S, et al. 2019. Distribution and bioprospecting potential of actinobacteria from Indian mangrove ecosystems. In: Microbial Diversity in Ecosystem Sustainability and Biotechnological Applications. Springer, New York.

Matthew RO, Ire F, Peterside NJF. 2020. Screening of actinomycetes from turmeric (Curcuma longa L.) and ginger (Zingiber officinale) rhizosphere for antifungal activity. J Adv Microbiol 20 (2): 18-28. DOI: $10.9734 /$ jamb/2020/v20i230214.

Patil R, Jeyasekaran G, Shanmugam S, et al. 2001. Control of bacterial pathogens, associated with fish diseases, by antagonistic marine actinomycetes isolated from marine sediments. Ind J Mar Sci 30 (4): 264-267.

Pereira F, Almeida JR, Paulino M, et al. 2020. Antifouling Napyradiomycins from marine-derived actinomycetes Streptomyces aculeolatus. Mar Drugs 18 (1): 63. DOI: 10.3390/md18010063.

Persson I, Tjerneld F, Hägerdal BH. 1991. Fungal cellulolytic enzyme production: A review. Proc Biochem 26 (2): 65-74. DOI: 10.1016/0032-9592 (91)80019-L. 
Reef R, Feller IC, Lovelock CE. 2010. Nutrition of mangroves. Tree Physiol 30 (9): 1148-1160. DOI: 10.1093/treephys/tpq048.

Remya M, Vijayakumar R. 2008. Isolation and characterization of marine antagonistic actinomycetes from the West coast of India. Med Biol 15 (1): 13-19.

Sabido EM, Tenebro CP, Suarez AFL, et al. 2020. Marine sedimentderived Streptomyces strain produces angucycline antibiotics against multidrug-resistant Staphylococcus aureus Harboring SCCmec type 1 gene. J Mar Sci Eng 8 (10): 734. DOI: 10.3390/jmse8100734.

Sapkota A, Thapa A, Budhathoki A, et al. 2020. Isolation, characterization, and screening of antimicrobial-producing actinomycetes from soil samples. Int J Microbiol 2020: 1-7. DOI: $10.1155 / 2020 / 2716584$.

Shaala LA, Youssef DT, Alzughaibi TA, et al. 2020. Antimicrobial Chlorinated 3-Phenylpropanoic acid derivatives from the Red Sea marine actinomycete Streptomyces coelicolor LY001. Mar. Drugs 18 (9): 450. DOI: 10.3390/md18090450.

Shah AM, Shakeel u R, Hussain A, et al. 2017. Antimicrobial investigation of selected soil actinomycetes isolated from unexplored regions of Kashmir Himalayas, India. Microbial Path 110: 93-99. DOI: 10.1016/j.micpath.2017.06.017.

Shamikh YI, El Shamy AA, Gaber Y, et al. 2020. Actinomycetes from the Red Sea sponge Coscinoderma mathewsi: isolation, diversity, and potential for bioactive compounds discovery. Microorganisms 8 (5): 783. DOI: 10.3390/microorganisms 8050783 .

Suresh RS, Younis EM, Fredimoses MJ. 2020. Isolation and molecular characterization of novel Streptomyces sp. ACT2 from marine mangrove sediments with antidermatophytic potentials. J King Saud Univ Sci 32 (3): 1902-1909. DOI: 10.1016/j.jksus.2020.01.020.

Talpur MKA, Qazi MA, Phulpoto AH, et al. 2020. Bioprospecting actinobacterial diversity antagonistic to multidrug-resistant bacteria from untapped soil resources of Kotdiji, Pakistan. Biologia 75 (1): 129-138.

Tistechok S, Skvortsova M, Luzhetskyy A, et al. 2019. Antagonistic and plant growth promoting properties of actinomycetes from rhizosphere Deschampsia antarctica Ė. Desv. (Galindez Island, Antarctica). Ukraine Antarctic J 1 (18): 140. DOI: 10.33275/1727-7485

Waithaka PN, Gathuru EM, Githaiga BM, et al. 2019. Microbial degradation of maize waste materials using actinomycetes isolated from Egerton University Soils, Njoro in Kenya. Intl Res J Biol Sci 1 (1): 31-36.

Yanti A, Setyawati T, Kurniatuhadi R. 2020. Composition and characterization of actinomycetes isolated from Nipah mangrove sediment, gastrointestinal and fecal pellets of Nipah worm (Namalycastis rhodhocorde). IOP Conf Ser Earth Environ Sci 550: 012003. DOI: 10.1088/1755-1315/550/1/012003.

Yi M, Lin S, Zhang B, et al. 2020. Antiviral potential of natural products from marine microbes. Eur J Med Chem 207: 112790. DOI: 10.1016/j.ejmech.2020.112790.

You JL, Cao LX, Liu GF, et al. 2005. Isolation and characterization of actinomycetes antagonistic to pathogenic Vibrio spp. from nearshore marine sediments. World J Microbiol Biotech 21 (5): 679-682. 